\title{
Experiencing the Unimaginable: the Collapse of the Rule of Law in Poland
}

\section{Miroslaw Wyrzykowski ${ }^{1}$}

Published online: 5 November 2019

(c) The Author(s) 2019

1. In Poland, in 2019, the constitutional crisis continues. The crisis was initiated in the autumn of 2015 and concerned the election by Parliament of three judges of the Constitutional Tribunal to the replace the judges already duly elected. The President of Poland refused to swear in the original three judges of the Constitutional Tribunal and the Prime Minister refused to publish the judgments of the Constitutional Tribunal concerning the constitutionality of the Constitutional Tribunal Act confirming the legality of the election of the three judges. The Acts passed in 2015 and 2016 regulate the Constitutional Tribunal in a way that is considered to violate the Constitution. The Constitutional Tribunal lost its role as the guardian of the Constitution. Further, Parliament, in violation of the Constitution, made changes in the organization and structure of the Supreme Court, inter alia forcing more than $30 \%$ of the judiciary into early retirement or interrupting the constitutionally-guaranteed six-year term of office of the First President of the Supreme Court. Furthermore, the new regulation regarding the National Council of the Judiciary has encroached on the term of office of the Council's judicial members. Moreover, this reform set in motion a process of the politicization of the Council because its new judiciary were appointed by Parliament and not—as used to be required—by the assemblies of judges of particular judicial orders. These, as well as many other regulations, indicate a process of a 'hostile takeover' of the constitutional order by changing the constitutional order through ordinary legislation: the parliamentary majority does not have the qualified majority required to formally amend the Constitution of the Republic of Poland. The regulations discussed above violate the basic tenets of the rule of law and have become the subject of an unequivocally negative reaction by international organizations and authorities (the European Union, the Council of Europe, and the UN) as well as associations representing general and constitutional courts.

One may say that there is no longer a constitutional crisis. There is rather an "il-legal" war against the Constitution of Poland carried on by the constitutional

Miroslaw Wyrzykowski

wyrzyk1925@gmail.com

1 University of Warsaw, Warsaw, Poland 
authorities: Parliament, the President and the government. The focus of that war is the independence of judiciary, the freedom of the media, the civil service, human rights and freedoms including the guaranties of fundamental rights No one is better prepared than Martin Krygier to analyse the mechanism for the collapse of the rule of law. His theoretical analyses of the essence of the rule of law, his reflections on the margin of the observed phenomena in the sphere of law and politics and his great emotional involvement in the values forming the essence of the rule of law and its place in contemporary constitutionalism entitle me to present the case of Poland as a state from this perspective-almost failed.

2. Over the past almost 4 years, starting in late 2015, Poland has experienced a loss of the meaning and value of the fundamental principles and foundations of the order of the modern constitutional state.

2.1 The starting point is the observation that the Republic of Poland is losing its internal state sovereignty. A sovereign state is a state which acts on the basis and within the limits of the law and in which the rules which the state establishes for its citizens are respected. The power of sovereignty is not unlimited, because contemporary sovereignty is bound by the standards of individual rights and freedoms. This makes it all the more difficult for those in power to exercise power. If sovereignty is limited, then the power of the representatives of sovereignty is even more limited. The limits of this power are set by the Constitution, international obligations and ordinary legislation, which must meet the minimum conditions for constitutionality. Representatives of sovereignty can only act on the basis and within the limits of the Constitution. A sovereign constitutional state cannot be called a sovereign state when its constitution is being violated by its organs.

2.2 We are also losing the constitutional identity of the Republic of Poland. In 2010 the Constitutional Tribunal, in a judgment concerning the Lisbon Treaty, set out several features of the constitutional identity of the Republic of Poland: respect for Polish statehood, democracy, the rule of law, social justice, the basis of the economic system, and finally ensuring the protection of the dignity of human rights.

These values were to serve as the basis for the constitutional order defining identity, i.e. the inalienable and most characteristic elements of the Polish system. They were to determine the limits of acceptable actions of public authority in the sphere of international relations, in particular the possibility of transferring the powers of the authorities to joint execution within the framework of the process of European integration. The analysis of the constitutional reality leads to the conclusion that the essence of the content of these values is hollowed out by the mechanism of ordinary legislation and political practice. Restricting agricultural property - as the basis of the economic system-to the extent that it infringes its essence, grossly infringing the principle of the separation of powers, in particular the independence of the judiciary, restricting the right of parliamentary opposition or undermining the reputation of the Republic of Poland on the international arena, which are only examples, call into question the essence of constitutional identity. The process of the loss of constitutional identity began with the violation of the rule of law in order to spread to other systemic values.

2.3. Another element that we are losing is parliamentarianism. While monitoring the activities of public authorities, we have directed the attention of the Polish 
and international public opinion to the process of destroying the rule of law. In the shadow of this process, an extremely effective and, at the same time, extremely dangerous process of destroying Polish parliamentarianism has taken place.

A parliament in which a Member, a representative of sovereignty but a member of a parliamentary minority, has $30 \mathrm{~s}$ to make a statement, cannot be considered to be a truly functioning parliament. Constitutional laws should not be passed in three readings within less than $4 \mathrm{~h}$, and the signing of the law by the President takes place electronically a few hours after its transmission by the Senate. The scale of the destruction of parliamentarianism is shown in the reports of the Team of Experts at the Stefan Batory Foundation, covering Poland's legislative activity since November 2015.

We are losing our legal security both at the national and international level. What the significance is of the way the law is made in Poland for the legal security of Polish citizens at the international level can be shown by the case of the Polish citizen Artur C. The Irish High Court in question had doubts as to whether an European Arrest Warrant issued by Poland should be duly executed due to deficiencies in the Polish justice system with the result that the person in question would possibly not receive a fair trial, and referred the matter to the EU Court of Justice for a preliminary ruling. Finally, after a thorough analysis of the situation in Poland, the Irish court decided that there were no grounds for not surrendering the charged person under the European Arrest Warrant. However, this case does show how the lack of confidence in Poland's implementation of the concept of the rule of law has a fundamental impact on legal security. Legal security is the essence of the rule of law and does not allow arbitrary action by any authority, not only the Sejm, but also the courts, the prosecutor's office or the government and its administrative bodies.

2.4. The weakening of the independence of the courts and judges until they lose their essence. The lack of effective guarantee mechanisms for the rule of law creates the necessary conditions for a hostile takeover of the state and its constitutional order by those who have gained political power in a democratic political process. One of the elements of a hostile takeover is the weakening of judicial independence and the independence of the judges.

The independence of the judiciary is a universal and absolute value. The minimum content of the independence of the judiciary is unconditional. The legislator has the competence, i.e. the right and the duty, to legislate in order to guarantee the independence of the judiciary. Every legislator, especially the Polish legislator, is bound by absolute, inviolable and non-transferable directives. They are as follows: (a) the mandate of Parliament concerns only the admissibility of extending and strengthening the guarantee of judicial independence, (b) the legislator is bound by an absolute and unconditional prohibition on weakening or restricting the independence of the judiciary, (c) this prohibition concerns the creation of both laws directly restricting independence and those indirectly restricting independence. In particular, it concerns the apparently neutral, 'technical' regulation of justice matters at all levels of the justice system and at all levels of regulation. But in practice these seemingly neutral or technical regulations create a technological sequence of intentions and the aim of which is to change the level of independence of the judiciary, (d) any regulation that reduces the guarantees of the independence of the judiciary-in 
relation to the state preceding the regulation-is a violation of the Constitution, (e) the conditions for excluding effective control over the law's compliance with the Constitution result in a change in the constitutional order of the state without changing the content of the Constitution, (f) it also means that we are dealing with a constitutional dispute. Such a constitutional tort is committed by all public authorities involved in the legislative process. ( $g$ ) The independence of the judiciary is functionally linked to other fundamental principles of constitutional democracy, such as democracy itself (e.g. determining the validity of elections) or human rights (the right of access to an independent court or the right to have one's case considered by a judge who has been properly appointed) or the mechanism for controlling the constitutionality of the law. The exclusion of an effective constitutional control mechanism is the first sign and, at the same time, the most obvious objective of limiting the independence of the judiciary. (h) A state that does not guarantee a minimum level of the independence of the judiciary is, from this perspective, a failed state.

2.5. There is an increasing risk of losing sustainable benchmarks for assessing the (non-)constitutional reality. This concerns, among other things, various types of evil interpretative and argumentative procedures. For example, the lack of an effective mechanism to restore/confirm the constitutionality of legislation does not mean that the mechanisms for assessing this state of affairs are excluded. Everyone has the right to assess the constitutionality of legislation on any issue. The effect of an evaluation is different-different when we are dealing with a judicial statement by the Constitutional Tribunal, different when an unconstitutional act is omitted by a common court, the Supreme Court or an administrative court, different when the author of a statement is a legal authority, a journalist or a citizen. There is no basis for the concept, although some would support such a concept, which assumes that the existence of a constitutional court and the right to make a binding decision on the compliance of a law with the Constitution precludes the right of other persons or institutions to assess the constitutionality of the law in force. The monopoly of the Constitutional Tribunal in ruling on the compliance of a law with the Constitution (with the effect of repealing an unconstitutional law) does not exclude the universal, civic right to interpret the constitution.

2.6. The experience of losing the premises of the rationality of one's own view of the situation may be the result of actions which take the nature of an argumentative fraud. An example may be a claim that judges, and lawyers in general, are not allowed to speak on matters related to the constitutional and statutory legal order, because this is a political matter, and judges are prohibited from engaging in political activity.

Another argumentary trap concerns an inefficient attempt to justify the dismissal of the first President of the Supreme Court due to reaching retirement age, which had been lowered in violation of the constitutional guarantee of judges' irrevocability. According to the perverse argumentation that the first President can only be a judge in office, Prof. Gersdorf found herself to be in the situation-by virtue of this change to the law-of a retired judge, so she could not therefore be the first President. This is seemingly logical, only that this logic is based on assumptions that intentionally omit the essence of the constitutionally guaranteed 6-year term of office of the First President of the Supreme Court. It is an abusive interpretation, 
having the appearance of legality and sound logic in order to achieve a goal that is prohibited by the Constitution. The Constitution prohibits any shortening-in any form and under any circumstances — of the 6-year term of office of the first President of the Supreme Court (similarly also the President of the Supreme Administrative Court).

It is not about counteracting changes or whatever we would call the processes taking place in the state. It is about making it impossible to impose a mask of legality for these processes. There is no consent for any 'Maskquerade Ball' because neither Giuseppe Verdi's score nor that of Arturo Toscanini stands on the desktop and because argumentary deception is a trap and blackmail, also emotional blackmail. Once we give into blackmail, we will never leave the corkscrew of ruthless evil. Argumentary deception is supposed to destroy the foundations of public reason. Sometimes it does so effectively.

2.7. The conflict between the public authorities of Poland and the bodies of the European Union leads to an unilateral loss of the essence of European values as defined in Article 2 of the Treaty on European Union. These values include respect for human dignity, freedom, democracy, equality, the rule of law and respect for human rights, including the rights of persons belonging to minorities. These values are common to the Member States in a society based on pluralism, non-discrimination, tolerance, justice, solidarity and equality between women and men. These values are the highest and most valuable qualities that define the essence of the community. They are legal obligations, but they also have their ethical justification in other EU rules, above all in responsible cooperation, full of mutual respect, loyalty and mutual assistance. These values form the common denominator of the Member States and the European Union as an organisation.

They could 1 day be compared to a lighthouse that points in the right direction and warns against the risk of shallow waters, not to mention the risk of running aground. Today we can compare it to a GPS function that allows us to program a direction and reach our destination safely and with the least waste of time and money. But we know that the correct functioning of the mechanism determining the direction and route is a derivative of many components and every one of them is equally important for the correct functioning of the whole mechanism. Moreover, if you are in one vehicle and have agreed from the very beginning what the rules are, do not try to turn on your own GPS.

2. 8. Then we lose credibility as a loyal traveller. We have already worked hard on this experience. Only negative effects are the result for everyone. However, the destruction in which we achieve mastery does not belong to the community of values. We lose the reputation built on trust and predictability. We are losing our seriousness as a state and as a society. We are losing the respect that underpins contemporary international relations within the framework of the Union. By losing all of this, we are not getting anything that could at least be a pretence or a hope of equivalent values.

A final remark concerns the loss of the significance of the Constitution as the supreme law of the Republic of Poland. The effective exclusion of the mechanism of control over the constitutionality of the law has made it easy to breach the Constitution. Having lost its previous normative significance, the 
Constitution-paradoxically-gains more and more symbolic significance. An example is the poster "KonsTYtucJA", which accentuates two personal pronouns. TY means "you", JA means "I". In fact, there is still a third "Ty", it means "He". Then I, you and he/she means-WE. We, the People, we are the Constitution. This poster is a symbol of the opposition to the violation of the Constitution. It is also a symbol of respect for and the societal recognition of the Constitution. While maintaining the measure, one can get the impression that the symbolism of the Constitution of Poland has its antecedents in the symbolism of the Constitution of 3 May 1791 and later the tragic consequences for Poland due to the stat being partitioned between Russia, Prussia and Austria. This symbolism lasted for 123 years.

Open Access This article is distributed under the terms of the Creative Commons Attribution 4.0 International License (http://creativecommons.org/licenses/by/4.0/), which permits unrestricted use, distribution, and reproduction in any medium, provided you give appropriate credit to the original author(s) and the source, provide a link to the Creative Commons license, and indicate if changes were made.

Publisher's Note Springer Nature remains neutral with regard to jurisdictional claims in published maps and institutional affiliations. 